\title{
СИСТЕМА ГАРАНТУВАННЯ ВКЛАДІВ ЯК ФАКТОР СТАБІЛЬНОСТІ КРИТИЧНОЇ ІНФРАСТРУКТУРИ У КРЕДИТНО-БАНКІВСЬКІЙ СФЕРІ
}

Іванов Ю. А.

Реалізація курсу на інтеграцію України в європейський політичний, економічний та правовий простір передбачає необхідність модернізації вітчизняного законодавства, в тому числі у кредитно-банківській сфері. Зокрема, йдеться і про послідовне впровадження концепції критичної інфраструктури та їі захисту як базису для розвитку правового забезпечення економічної безпеки держави. Зазначене зумовлює актуальність даної статті. Проблеми становлення та розвитку системи гарантування вкладів в Україні розглядаються як в юридичній, так і в економічній науковій літературі. Серед публікацій юридичного спрямування варто виділити, насамперед, праці Т.В. Мазур [1], К.О. Алексійчук [2]. Економічним аспектам цієї проблематики присвячено монографію І.М. Михайловської та С.В. Безвуха [3], дисертаційне дослідження Д.Б. Чеховського [4]. Однак проблеми розбудови системи гарантування вкладів у контексті захисту критичної інфраструктури у кредитно-банківській сфері не розглядалися. Стаття присвячена аналізу сучасного стану та перспектив вдосконалення системи гарантування вкладів в інтересах забезпечення стабільного функціонування критичної інфраструктури у кредитно-банківській сфері. Метою статті $\epsilon$ з'ясування значення системи гарантування вкладів для забезпечення стабільного функціонування критичної інфраструктури у кредитно-банківській сфері та визначення правових можливостей для їі подальшого вдосконалення.

Ключові слова: банківська система, критична інфраструктура, система гарантування вкладів.

Реализация курса на интеграцию Украины в европейское политическое, экономическое и правовое пространство предполагает необходимость модернизации отечественного законодательства, в том числе в кредитно-банковской сфере. В частности, речь идет и о последовательном внедрении концепции критической инфраструктуры и ее защите в качестве базиса для развития правового обеспечения экономической безопасности государства. Указанное обусловливает актуальность данной статьи. Проблемы становления и развития системы гарантирования вкладов в Украине рассматриваются как в юридической, так и в экономической научной литературе. Среди публикаций юридического направления следует выделить, прежде всего, работы Т.В. Мазур [1], Е.А. Алексийчук [2]. Экономическим аспектам этой проблематики посвящена монография И.Н. Михайловской и С.В. Безухий [3], диссертационное исследование Д.Б. Чеховского [4]. Однако проблемы развития системы гарантирования вкладов в контексте защиты критической инфраструктуры в кредитно-банковской сфере не рассматривались. Статья посвящена анализу современного состояния и перспектив усовершенствования системы гарантирования вкладов в интересах обеспечения стабильного функционирования критической инфраструктуры в кредитно-банковской сфере. Целью статьи является выяснение значения системы гаранти-

Іванов Ю. А., 2019 рования вкладов для обеспечения стабильного функционирования критической инфраструктуры в кредитно-банковской сфере и определение правовых возможностей для дальнейшего совершенствования.

Ключевые слова: банковская система, критическая инфраструктура, система гарантирования вкладов.

The well-known author's publications concerning the definition of critical infrastructure components in the financial sector in general and in its credit and banking segment in particular, do not mention the Deposit Guarantee Fund. Meanwhile, its importance for the stable functioning of the banking system in the context of systemic transformations, accompanied by the withdrawal from the market and liquidation of a significant number of banks, is extremely important. In addition, a considerable amount of assets of liquidated banks are accumulated on the Fund's balance sheet, the preservation and sale of which at a market-based price is a matter of national security. This is conditioned by the fact that, unfortunately, the formation of the Fund's funds is currently carried out not only at the expense of the contributions of participating banks, but also through the involvement of other sources, including governmental ones. Accordingly, there is a direct dependency: the more efficient the Fund's work with its available assets, the less need for additional funding from the state.

The importance of the deposit guarantee system for ensuring the stability of critical infrastructure in the credit and banking sector is due, first of all, to the specifics of the bankruptcy institute in the domestic economic legislation. Implementation of the course on integration of Ukraine into the European political, economic and legal space requires the modernization of national legislation, including in the credit and banking sphere. In particular, there is a consistent implementation of the concept of critical infrastructure and its protection as a basis for the development of legal support for the economic security of the state. The above determines the relevance of this article. Problems of formation and development of deposit guarantee system in Ukraine are considered in both legal and economic scientific literature. Among the publications of the legal direction, it is worth noting, above all, the works of TV Mazur [1], K.O. Alexeychuk [2]. The economic aspects of this issue are devoted to the monograph by I.M. Mikhailovskaya and S.V. Bezvuha [3], dissertation research DB Chekhovsky [4]. However, the problems of building a deposit guarantee system in the context of critical infrastructure protection in the banking sector have not been addressed. The article is devoted to the analysis of the current state and prospects of improving the deposit guarantee system in order to ensure the stable functioning of the critical infrastructure in the credit and banking sector. The purpose of the article is to clarify the importance of the deposit guarantee system for ensuring the stable functioning of the critical infrastructure in the credit and banking sphere and to identify the legal possibilities for further improvement.

Key words: banking system, critical infrastructure, deposit guarantee system. 
Постановка проблеми. У відомих авторові публікаціях, які стосуються визначення складових частин критичної інфраструктури у фінансовій сфері загалом та у її кредитно-банківському сегменті зокрема, не згадується про Фонд гарантування вкладів фізичних осіб. Між тим його значення для стабільного функціонування банківської системи в умовах системних трансформацій, що супроводжуються виведенням із ринку та ліквідацією значної кількості банків, є вкрай важливим. До того ж на балансі Фонду акумулюється значна кількість активів ліквідованих банків, збереження та реалізація яких за ринково обґрунтованою ціною $є$ питанням національної безпеки. Зазначене зумовлюється тим, що формування коштів Фонду, на жаль, наразі значною мірою здійснюється не лише за рахунок внесків банків-учасників, а із залученням інших джерел, у тому числі державних. Відповідно, спостерігається пряма залежність: чим ефективніша робота Фонду з наявними в його розпорядженні активами - тим менша необхідність у додатковому фінансуванні з боку держави.

Значення системи гарантування вкладів для забезпечення стійкості критичної інфраструктури у кредитно-банківській сфері зумовлене, передусім, специфікою інституту банкрутства у вітчизняному господарському законодавстві. Так, зокрема, на банки не поширюється дія Закону України «Про відновлення платоспроможності боржника або визнання його банкрутом» [5]. Про це йдеться в частині 8 статті 36 Закону України «Про систему гарантування вкладів фізичних осіб» [6]. Термін «банкрут» у суто юридичному розумінні до банків взагалі не застосовний. Натомість банк може бути визнаний неплатоспроможним із подальшим здійсненням процедур, необхідних для його виведення з ринку. Ці процедури кардинально відрізняються від процедур банкрутства юридичних осіб, хоч мета їх збігається: звільнити ринок від неефективно господарюючих суб'єктів, неспроможних розрахуватися за своїми борговими зобов'язаннями. Основна принципова відмінність полягає в тому, що процедури банкрутства реалізовуються в судовому порядку, а виведення з ринку неплатоспроможних банків відбувається в рамках особливої адміністративної процедури, яка отримала назву тимчасової адміністрації і здійснюється Фондом гарантування вкладів фізичних осіб. Такий самий підхід зберігся і у прийнятому восени 2018 року Кодексі України із процедур банкрутства, який має набрати чинності через шість місяців після офіційного опублікування. У частині другій статті 2 цього Кодексу зазначено, що законодавство про відновлення платоспроможності боржника або визнання його банкрутом не поширюється на банки, що виводяться з ринку або ліквідуються відповідно до Законів України «Про банки і банківську діяльність» [7] та «Про систему гарантування вкладів фізичних осіб».

Виклад основного матеріалу. Загалом правова природа системи гарантування вкладів частково ґрунтується на положеннях Господарського кодексу України [8], зокрема його статті 201, якою визначено загальногосподарські (публічні) гарантії як один із різновидів заходів, спрямованих на забезпечення виконання господарських зобов'язань. Зокрема, зазначеною статтею встановлено, що з метою нейтралізації несприятливих наслідків від кримінальних правопорушень у сфері господарської діяльності законом може бути передбачено обов'язок комерційних банків, страховиків, акціонер- них товариств та інших суб'єктів господарювання, які залучають кошти або цінні папери громадян і юридичних осіб, передавати частину своїх коштів для формування єдиного страхового фонду публічної застави. Таким чином, існує юридична можливість створення подібних механізмів забезпечення виконання зобов'язань не лише у кредитно-банківській сфері, а й на ринку страхових послуг та ринку цінних паперів. Водночас на практиці ці можливості реалізовано саме на ринку банківських послуг. Щоправда, в наявному на тепер вигляді система гарантування вкладів за своїм змістом виходить за межі гарантій, передбачених вищевказаною статтею Господарського кодексу України, оскільки йдеться про захист прав вкладників у всіх випадках ліквідації неплатоспроможних банків, незалежно від причин настання їх неплатоспроможності, а не лише у випадках нейтралізації несприятливих наслідків від кримінальних правопорушень. Принагідно слід зазначити, що застосований у Господарському кодексі України термін «комерційний банк» не відповідає термінології Закону України «Про банки і банківську діяльність», який оперує терміном «банк». Натомість про комерційний банк ішлося в попередній редакції зазначеного Закону від 20 березня 1991 року [9]. У процесі реформування банківського законодавства було з'ясовано, що додавання слова «комерційний» не несе жодного додаткового смислового навантаження, не вказуючи ані на форму власності, ані на організаційно-правову форму чи будь-які інші характеристики. Якщо ж передбачити, що слово «комерційний» вказує на підприємницький (комерційний) характер банківської діяльності, то й у цьому немає жодної необхідності, адже за чинним законодавством банки в Україні можуть утворюватися та функціонувати лише у формі господарських товариств (а саме у формі акціонерних товариств та кооперативних банків), які за визначенням $€$ суб'єктами підприємницької діяльності. Таким чином, убачається доцільним для забезпечення єдності та узгодженості загального господарського та банківського законодавства внести відповідні зміни й до Господарського кодексу України.

Інституційний механізм системи гарантування вкладів в Україні реалізовано у формі Фонду гарантування вкладів фізичних осіб (далі -депозити, зроблені іншими кредитними установами від свого імені і за власний рахунок;

- всі інструменти, які підпадають під визначення «власних коштів» у статті 2 Директиви 89/299/ЄЕС від 17 квітня 1989 року про власні кошти кредитних установ [15];

- депозити, отримані внаслідок операцій, у зв'язку з якими було винесено кримінальний обвинувальний вирок про відмивання грошей відповідно до статті 1 Директиви Ради 91/308/ЄЕС від 10 червня 1991 року щодо запобігання використанню фінансової системи для відмивання грошей [16].

Перші два пункти з наведеного переліку потребуватимуть імплементації в законодавство України лише після поширення дії системи гарантування вкладів на кошти юридичних осіб. Що ж до третього пункту, то він має бути впроваджений якнайшвидше. При цьому доцільно поширити обмеження також на депозити, призначені для фінансування тероризму та розповсюдження зброї масового знищення. 
Додатково до депозитів, які в імперативному порядку виключаються з виплат гарантійними схемами, нормою ч. 2 статті 7 Директиви № 94/19/€С державам надається можливість передбачити, що певні вкладники або депозити, перелік яких наведено у Додатку I, виключаються з гарантії або ж їм надається нижчий рівень гарантій.

Зі змісту Директиви № 94/19/€С випливає, що допускається існування в державі кількох схем гарантування депозитів. При цьому кожна кредитна установа зобов'язана належати хоча б до однієї з них. В Україні ж залишається невирішеним питання щодо залучення до участі в системі гарантування вкладів АТ «Державний ощадний банк України». Так, зокрема, відповідно до пункту 6 розділу $X$ «Прикінцеві та перехідні положення» Закону України «Про систему гарантування вкладів фізичних осіб» його дія не поширюється на акціонерне товариство «Державний ощадний банк України» (до прийняття відповідного закону щодо участі такого банку у Фонді). Статтею 3 Директиви № 94/19/ ЄC передбачено, що держава може звільнити кредитну установу від обов'язку належати до схем гарантування депозитів, якщо така кредитна установа належить до системи, яка захищає саму кредитну установу $\mathrm{i}$, зокрема, забезпечує їі ліквідність і платоспроможність, гарантуючи вкладникам захист, який щонайменше еквівалентний тому, що надається схемою гарантування депозитів. Однак така система не може складатися 3 гарантії, наданої кредитній установі самою державою-членом або якимось з місцевих або регіональних органів. До того ж, користуючись таким привілейованим становищем, зазначений державний банк отримує певні конкурентні переваги на ринку. Не сплачуючи внески до Фонду, цей банк може або пропонувати клієнтам підвищені ставки за депозитами, або ж просто отримати дешевший ресурс для здійснення активних операцій та забезпечення власної прибутковості, що в будь-якому разі не повністю узгоджується із приписами антимонопольно-конкурентного законодавства України. Тож очевидно, що АТ «Державний ощадний банк України» має бути залучений до участі в системі гарантування вкладів на загальних підставах.

Під час співставлення характеристик вітчизняної системи гарантування вкладів зі стандартами ЄС, до яких вона має бути адаптована, важливим показником $\epsilon$ також рівень покриття депозитів. Так, в Європейському Союзі протягом тривалого часу відповідно до статті 7 Директиви № 94/19/€С схеми гарантування депозитів мали передбачати, щоб сукупні депозити кожного вкладника покривалися сумою до 20 тисяч екю (з 1 січня 1999 року - 20 тисяч євро) в разі недоступності депозитів. Під впливом світової фінансово-економічної кризи у 2009 році Директивою № 2009/14/ЄС [17] стандарти щодо гарантування депозитів були суттєво скореговані. Зокрема, було передбачено підвищення рівня покриття депозитів гарантійними схемами до 100 тисяч євро з тенденцією до подальшого зростання. В Україні ж сума граничного розміру відшкодування коштів за вкладами, як уже зазначалося, встановлена на рівні лише 200 тисяч гривень. Водночас, порівнюючи ці суми, слід враховувати, що переважна більшість усіх вкладів у вітчизняних банках не перевищують актуальний на сьогодні граничний розмір відшкодування з Фонду. Щоправда, цілком ймовірно, що відносно невеликі розміри депозитів якраз і зумовлені бажанням вкладників не позбавляти себе можливості скористатися гарантіями Фонду в разі неплатоспроможності банку. Тому у процесі адаптації законодавства України до стандартів $\in C$ все ж доцільно рівень гарантування вкладів поступово збільшувати.

Поряд із рівнем покриття депозитів не менш важливим $\epsilon$ порядок визнання кредитної установи неплатоспроможною та строк, протягом якого гарантійна схема має забезпечити здійснення виплат. Зі змісту ч. 3 статті 1 Директиви № 94/19/ЄС випливає, що неплатоспроможність кредитної установи може бути встановлена:

- в адміністративному порядку за рішенням відповідних компетентних органів;

- у судовому порядку.

Строки для визнання неплатоспроможності кредитної установи в судовому порядку Директивою № 94/19/ $\in C$ не встановлені. Для адміністративного порядку передбачено, що компетентні органи роблять висновок якомога швидше і не пізніше двадцять одного дня після того, як вони вперше переконалися, що кредитна установа не виплатить депозити, строк виплати яких вже надійшов. Згодом Директивою № 2009/14/ ЄC цей строк було скорочено до п'яти днів. Вклад, для якого встановлена неможливість його повернення власнику згідно з юридичними та контрактними умовами, позначено терміном «невиплачуваний рахунок». Із дня віднесення депозиту у встановленому порядку до категорії невиплачуваних рахунків починається відлік строку для оплати схемами гарантування депозитів належним чином перевірених вимог вкладників. Відповідно до ч. 1 статті 10 Директиви № 94/19/ЄС цей строк мав складати три місяці. У подальшому його скоротили спочатку до двадцяти, а згодом - до десяти днів. У статті 2 Закону України «Про систему гарантування вкладів фізичних осіб» також було визначено схоже за змістом поняття «недоступність вкладів». Однак у 2015 році це визначення із Закону вилучене, адже у вітчизняній системі гарантування вкладів воно не мало практичного сенсу, оскільки реалізація вкладниками права на одержання відшкодування з Фонду зумовлюється настанням іншого юридичного факту, а саме початком процедури виведення неплатоспроможного банку з ринку. У частині 1 статті 76 Закону України «Про банки і банківську діяльність» викладено перелік підстав, за наявності яких НБУ в імперативному порядку зобов'язаний прийняти рішення про віднесення банку до категорії неплатоспроможних. Однак при цьому законодавець не встановив строк, в межах якого НБУ має прийняти таке рішення. Натомість в ЄС такий строк, як уже зазначалося, чітко визначений. Тому в цьому аспекті вітчизняне законодавство потребує вдосконалення, адже на практиці зволікання з віднесенням банку до категорії неплатоспроможних може призводити до втрати активів, які могли б бути використані для задоволення вимог кредиторів. Що ж до подальших дій у разі визнання банку неплатоспроможним, то вони законодавством України достатньо чітко регламентовані, в тому числі і за строками.

Висновки. Викладене дає підстави для таких основних висновків:

- система гарантування вкладів $€$ важливим фактором стабільності критичної інфраструктури у кредит- 


\section{Економічна безпека держави: теорія і практика}

но-банківській сфері, адже від її досконалості значною мірою залежить нарощування вітчизняними банками, в тому числі системно важливими, обсягів депозитів;

- наявна в Україні система гарантування вкладів за низкою показників має певні резерви для вдосконалення, передусім у напрямку національно-правової імплементації європейських стандартів відповідно до міжнародно-правових зобов'язань за Угодою про асоціацію між Україною та ЄС;

- приведення системи гарантування вкладів у повну відповідність до стандартів ЄС сприятиме стабільному функціонуванню банківської системи України та забезпеченню економічної безпеки держави.

Перспективи подальших досліджень. Подальші дослідження варто спрямувати на пошук шляхів оптимізації взаємодії Фонду гарантування вкладів фізичних осіб та НБУ щодо захисту критичної інфраструктури у кредитно-банківській сфері.

\section{Література}

1. Мазур Т.В. Система гарантування вкладів фізичних осіб у банках. Сучасний стан і перспективи розвитку: монографія. Київ : Київський національний ун-т ім. Тараса Шевченка, 2010. 198 с.

2. Алексійчук К.О. Фінансово-правові засади гарантування банківських вкладів в Україні : автореф. дис. ... канд. юрид. наук : спец. 12.00 .07 ; Нац. авіац. ун-т. Київ, 2014. 18 с.

3. Михайлівська І.М., Безвух С.В. Формування системи захисту банківських вкладів фізичних осіб та суб'єктів господарювання в Україні : монографія. Хмельницький : ХНУ, 2013. 174 c.

4. Чеховський Д.Б. Механізм гарантування банківських вкладів в Україні : автореф. дис. ... канд. екон. Наук : спец. 08.00.08. Чернігів : Черніг. нац. технол. ун-т., 2015. 20 с.

5. Про відновлення платоспроможності боржника або визнання його банкрутом: Закон України від 14 травня 1992 р. № 2343-XII / Верховна Рада України. Відомості Верховної Ради України. 1992. № 31. Ст. 440.

6. Про систему гарантування вкладів фізичних осіб : Закон України від 23 лютого 2012 р. № 4452-VI / Верховна Рада України. Відомості Верховної Ради України. 2012. № 50. Ст. 564 .

7. Про банки і банківську діяльність : Закон України від 7 грудня 2000 р. № 2121-III / Верховна Рада
України. Відомості Верховної Ради України. 2001. № 5-6. Ст. 30.

8. Господарський кодекс України : Закон України від 16 січня 2003 р. № 436-IV / Верховна Рада України. Відомості Верховної Ради України. 2003. № 18. № 19-20. № 21-22. СТ. 144.

9. Про банки і банківську діяльність : Закон України від 20 березня 1991 р. № 842-XII / Верховна Рада України. Відомості Верховної Ради України. 1991. № 25. Ст. 281.

10. Про заходи щодо захисту прав фізичних осіб вкладників комерційних банків України : Указ Президента України від 10 вересня 1998 р. №996/98 / Президент України. Офіційний Вісник України. 1998. № 37 від 01.10.1998 р.

11. Конституція України : Закон України від 28 червня 1996 р. № 254к/96-ВР / Верховна Рада України. Відомості Верховної Ради України. 1996. № 30. Ст. 141.

12. Про Фонд гарантування вкладів фізичних осіб : Закон України від 20 вересня 2001 р. № 2740-III / Верховна Рада України. Відомості Верховної Ради України. 2002. № 5. СТ. 30.

13. Угода про асоціацію між Україною, 3 однієї сторони, та Європейським Союзом i його державами-членами, з іншої сторони // Урядовий портал. URL : http://www. kmu.gov.ua/ (дата звернення: 05.02.2019).

14. Директива № 94/19/ЄС про систему гарантування депозитів // База даних «Законодавство України». URL : http://zakon4.rada.gov.ua/ laws/show/994_275 (дата звернення: 05.02.2019).

15. Директива № 89/299/ЄЕС про власні кошти кредитних установ // База даних «Законодавство України». URL : http://zakon1.rada.gov.ua/laws/show /994_450 (дата звернення: 05.02.2019).

16. Директива Ради 91/308/ЄЕС щодо запобігання використанню фінансової системи для відмивання грошей // База даних «Законодавство України». URL : http://zakon4.rada. gov.ua/laws/show/994_148 (дата звернення: 05.02.2019).

17. Directive 2009/14/EC amending Directive 94/19/ EC on deposit-guarantee schemes as regards the coverage level and the payout delay. URL : http://eur-lex.europa.eu/ legal-content /EN/TXT/PDF/?uri=CELEX:32009L0014\& rid=1 (дата звернення: 05.02.2019).

Іванов Ю. А., кандидат юридичних наук, доцент, докторант Національної академії Служби безпеки України 